\title{
Assessing Sandhill Crane Roosting Habitat along the Platte River, Nebraska
}

\begin{abstract}
Each spring approximately 500,000 sandhill cranes and some endangered whooping cranes use the Central Platte River Valley in Nebraska as a staging habitat during their migration north to breeding and nesting grounds in Canada, Alaska, and the Siberian Arctic. Over the last century changes in the flow of the river have altered the river channels and the distribution of roost sites. USGS researchers studied linkages between water flow, sediment supply, channel morphology, and preferred sites for crane roosting. These results are useful for estimating crane populations and for providing resource managers with techniques to understand crane habitats.
\end{abstract}

$\mathrm{O}$ ver the last century, upstream waterresource development has affected the delivery of water and sediment to the central Platte River by eliminating high flows from the river and decreasing the sediment supply (Williams, 1978; Eschner and others, 1983). These changes have resulted in channel incision and vegetation encroachment along the riparian corridor. The once braided, wide, and shallow channels of the Platte have narrowed and deepened, and the sediment in these channels has become significantly coarser (Kinzel and others, 1999). During the same period of time, wetland meadow

In cooperation with Federal, State, and local stakeholders, the U.S. Geological Survey (USGS) initiated the Platte River Program (http://mcmcweb. er.usgs.gov/platte), a multidisciplinary effort. As part of the study, scientists in the National Research Program (NRP) in the hydrological sciences focused their research efforts on understanding how changes in water flow and sediment transport affect roosting sites for cranes. This study provides information to evaluate the effectiveness of management actions taken to improve the availability of roosting habitat for cranes, such as creation of wetland meadows, vegetation clearing and river flow manipulation. habitat, which provides a key source of protein for cranes, has decreased (Sidle and others, 1989). The changes in river morphology and distribution of wetland meadows are believed to have altered the nocturnal roosting habitat used by cranes (U.S. Fish and Wildlife Service, 1981; Krapu and others, 1984; Faanes and LeValley, 1993).

\section{Video Images of Roosting Cranes}

Cranes roost in the river at night, arriving at their roosts approximately one hour after sunset and leaving before sunrise. Synoptic surveys of roosting cranes were conducted at night by using an aerial thermal infrared video system. The video images were used in a geographical information system (GIS) to produce a map of sandhill crane roosting areas along the 130 kilometers of river between Lexington and Grand Island, Nebraska (Kinzel

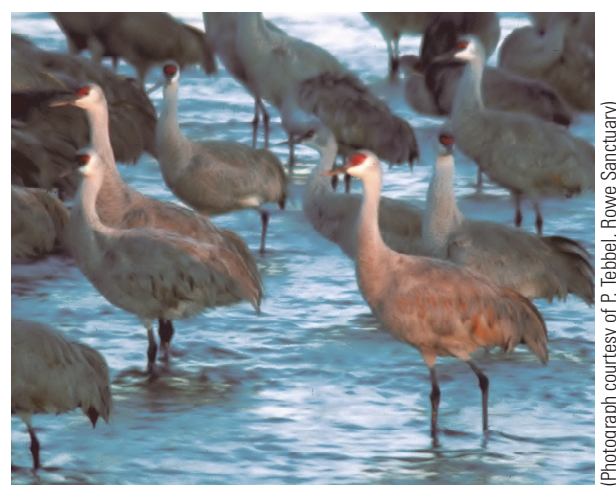

During the spring, the cranes roost in the central Platte River from dusk until dawn.

and others, 2001). Video was collected from high altitudes ( 1200 meters above the river) to resolve roosting flocks of sandhill cranes across the entire width of channels along the central Platte River and at low altitudes ( $\sim 300$ meters above the river) to resolve individual sandhill cranes. Images from low altitude are used to compute the spatial density of the birds within the roosting areas. Estimates are made of the crane population by multiplying the roost areas and the spatial densities. By applying this methodology, the number of cranes roosting in the central Platte River during the 2000, 2001 and 2002 infrared surveys were 552,000, 488,000 , and 486,000 birds, respectively. The highest concentration of sandhill cranes occurs near the National Audubon Society's Rowe Sanctuary.

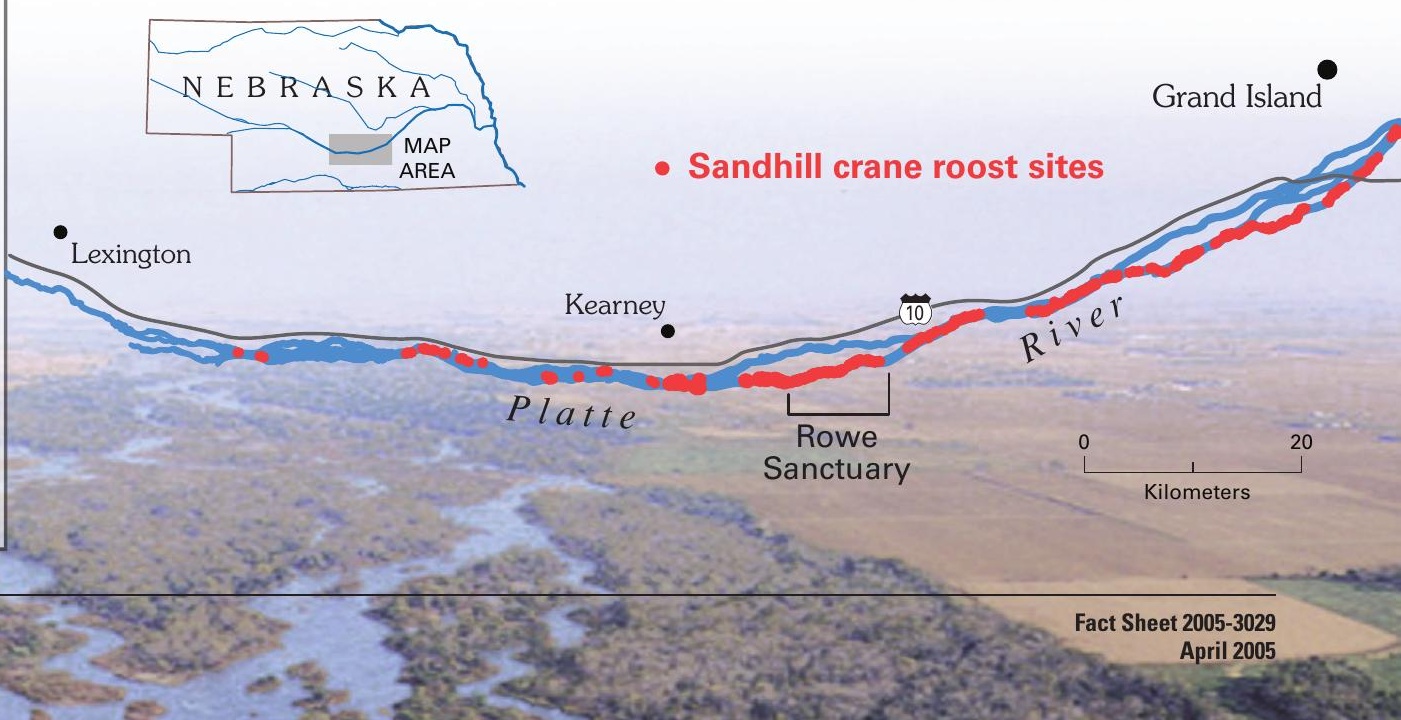




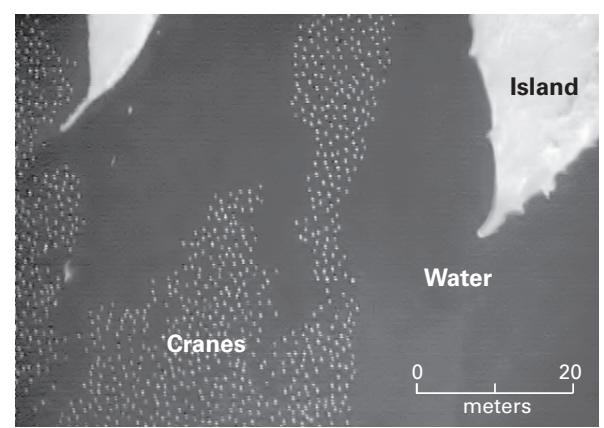

Low altitude aerial image of individual sandhill cranes roosting in the Platte River. The land appears light gray, the water dark gray, and the roosting cranes as small gray dots.

\section{Sandbar Morphology and Hydraulic Modeling}

The next part of the study was to relate the observed crane roosting sites to river morphology and hydraulics in the reach of the river near the Rowe Sanctuary. A survey-grade global positioning system was used to produce a detailed topographic map of the river channel, islands, sandbars and banks. The topographic map was used in a multi-dimensional hydraulic model to obtain river depths and velocities for specified discharges.
The hydraulic modeling was carried out with the USGS-developed public domain Multi-dimensional Surface Water Modeling System (MD_SWMS, available at http://wwwbrr.cr.usgs.gov/projects/ SW_Math_mod/OpModels/MD_SWMS/ index.htm). A vertically averaged twodimensional model was used to predict the spatial distribution of water depth and velocity along the study reach for selected stream flows (figure below).

The crane roost maps defined from the infrared video were overlain on the flow modeling results to identify the ranges in depth and velocity preferred by roosting cranes (figure right). Cranes generally prefer to roost in water depths less than 0.40 meters with velocities less than 0.70 meters per second. By examining these results at several stream flows, it was determined that the largest amount of available roosting habitat occurs at the Rowe Sanctuary when the stream flow in this channel is about 37 cubic meters per second. These model results were computed by assuming the riverbed is fixed and immobile. In actuality, at higher stream flows, sand could be deposited on the submerged sandbars, increasing their

Output from modeling showing water depth and velocity distributions along the Rowe Sanctuary in the Platte River for a stream flow of 57 cubic meters per second.
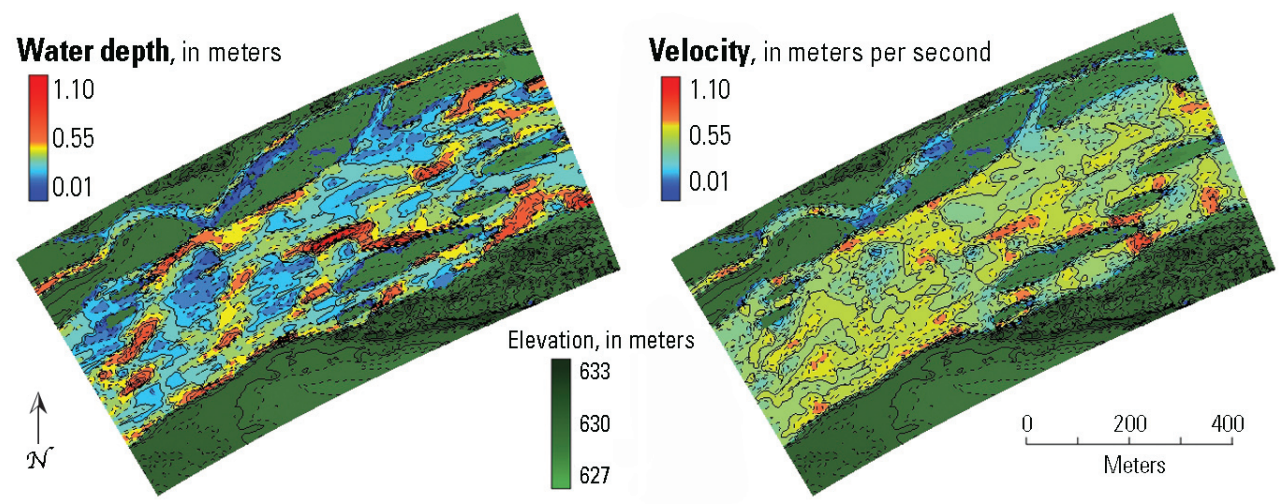

Histogram showing the ranges of depths and velocities used by roosting cranes in the Rowe Sanctuary study reach.

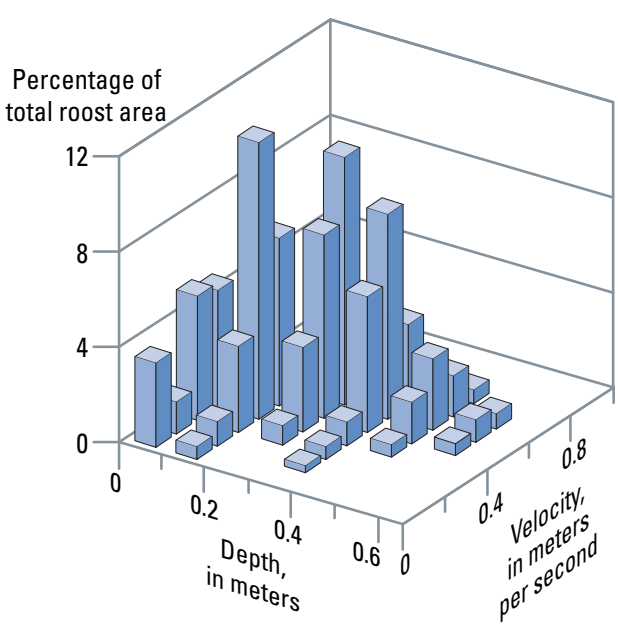

elevation, which may increase the quantity of available habitat. Investigating these effects would require modifying the model to incorporate sediment transport and verifying what influence this might have on the sandbars.

The results of this research provide a direct linkage between crane roosting habitat and river flows in the Platte. The methodology described shows how remote sensing, hydraulic modeling, and habitat assessments can be used to develop scientific tools for evaluating the efficacy of management actions.

\section{P.J. Kinzel, J.M. Nelson, and R.S. Parker, USGS, Denver, Colorado}

Information about other projects
underway in the National Research
Program can be found on the Internet
at http://water.usgs.gov/nrp/

Information about other projects underway in the National Research at http://water.usgs.gov/nrp/

\section{References}

Eschner, T.R., Hadley, R.F., and Crowley, K.D., 1983, Hydrologic and morphologic changes in the channels of the Platte River basin in Colorado, Wyoming and Nebraska: A historical perspective: U.S. Geological Survey Professional Paper 1277-A, Reston, Virginia, 39 pp.

Faanes, C.A., and LeValley, M.J., 1993, Is the distribution of sandhill cranes on the Platte River changing?: Great Plains Research 3, p. 297-304.

Kinzel, P.J., Nelson, J.M., Parker, R.S., Bennett, J.P., and Topping, D.J., 1999, Grain-size evolution of the Platte River, 1931-1998, in Proceedings of the 10th Platte River Basin Ecosystem Symposium, February 23-24, 1999, Kearney, Nebraska, p. 9-14.
Kinzel, P.J., Parker, R.S., Nelson, J.M., Starbuck, M., and Davis, L., 2001, Mapping sandhill crane roost sites along the central Platte River using aerial infrared videography, in Proceedings of the 11th Platte River Basin Ecosystem Symposium, February 27, 2001 Kearney, Nebraska, p. 8

Krapu, G.L., Facey, D.E., Fritzell, E.K., and Johnson, D.H., 1984, Habitat use by migrant sandhill cranes in Nebraska: Journal of Wildlife Management, v. 48, no. 2, p. 407-417.

Sidle, J.G., Miller, E.D., and Currier, P.J., 1989, Changing habitats in the Platte River Valley of Nebraska: Prairie Naturalist, v. 21, no. 2, p. 91-104.
U.S. Fish and Wildlife Service, 1981, The Platte River Ecology Study: U.S. Fish and Wildlife Service Special Scientific Report, Jamestown, North Dakota. 187 pp.

Williams, G.P., 1978, The case of the shrinking channelsThe North Platte and Platte Rivers in Nebraska: U.S. Geological Survey Circular 781, Arlington, Virginia, $48 \mathrm{pp}$.

For Additional Information

Chief Scientist for Hydrology

U.S. Geological Survey

436 National Center

Reston, Virginia 20192 